\title{
Response of Sugar Beet to Micronutrients Foliar Spray under Different Nitrogen Fertilizer Doses
}

\author{
H.E.A., Nemeata Alla, E.A.E. Nemeata Alla and A.A.E. \\ Mohamed* \\ Sugar Crop Res. Inst., Agric. Res. Center, Giza and "Agronomy \\ Dept., Fac. Agric., Kafrelsheikh, Univ., Kafrelsheikh, Egypt.
}

\begin{abstract}
7 HE PRESENT investigation was carried out at the Experimental Farm of Sakha Agricultural Research Station, ARC, at Kafrelsheikh Governorate, Egypt during 2012/2013and 2013/2014 seasons. Two field experiments were conducted to study the effect of different foliar spraying treatments, i.e., spraying with distilled water, spraying with micronutrients mixture once after 60 days from sowing and twice after, 60 and 75 days from sowing and four nitrogen rates, i.e., $60,75,90$ and $105 \mathrm{~kg} \mathrm{~N} / \mathrm{fad}$ ( as soil application ) on yield, yield components and quality of sugar beet as well as to minimizing costs of mineral fertilization and environmental pollution. The experimental design was split plot design with three replications. The main results of this investigation clear that nitrogen fertilizer up to $105 \mathrm{~kg} \mathrm{~N} / \mathrm{fad}$ and foliar twice with micronutrients mixture significantly increased root length and diameter, dry matter accumulation/plant, top and root yield/fad as well as sugar yield/fad in both seasons. The inverse was true in TSS, sucrose and juice purity percentages. Whereas, raising soil application of nitrogen from 60 to $105 \mathrm{~kg} \mathrm{~N} / \mathrm{fad}$ and foliar spraying with micronutrients mixture caused a marked decrease in the previously mentioned traits.
\end{abstract}

Generally, it can be concluded that soil application of nitrogen fertilizer at the rate of $105 \mathrm{~kg} \mathrm{~N} / \mathrm{fad}$ and foliar spraying sugar beet plants twicely with micronutrients mixture could be recommended for optimum root and sugar yield per unit area.

Keywords: Sugar beet, Micronutrients Foliar, Nitrogen .

Sugar beet (Beta vulgaris L.) is the second source for sugar production after sugar can. The Egyptian Government encourages sugar beet growers to increase the cultivated area with sugar beet for decreasing the gab between sugar production and consumption. Improvement of sugar beet production can be achivied through optimizing the cultural practices.

Nitrogen is an essential nutrient for sugar beet plants, decidedly the amount and method of nitrogen application required to produce the maximum root and sugar yields. Soil application of fertilizers is the oldest and most common method practiced throughout the world for all crops. It was based on the fact that primary function of the root is to plant nutrient from the soil. 
Nitrogen application as soil fertilizer increased length and diameter of roots (EL- Zayat, 2000; Nemeat-Alla \& El- Geddawy, 2001; Abo El -Wafa, 2002 and Badr, 2004) dry mater accumulation/plant (Hassanin \& Elayan, 2000; Nemeat-Alla et al., 2002; Ouda, 2006; Aboushady et al., 2007; EL- Fedaly et al., 2011 and Essam et al., 2012), root, top and sugar yields /fad (Ouda, 2000; Bader, 2004; Nemeat-Alla et al., 2007a; Allam, 2008, and Essam et al., 2012), TSS, sucrose and juice purity percentages were decreased by increasing nitrogen rates (Azab et al., 2000; Ouda, 2006; Allam, 2008; El- Fedaly et al., 2011 and Essam et al., 2012).

Most of Egyptian soil suffered from micronutrients deficiency as a results of the intensive cropping, low organic mater content in soil and alkaline condition of soil which decreases the availability of many nutrients. Times of micronutrients application gave the maximum yield and quality for sugar beet crop. Therefore, fertilization rate for nitrogen and number of application for micronutrients is very important and become target to many investigators, Abd El- Hadi et al. (2002), Abd El- Gawad et al. (2004), Ismail \& AboEl- Ghait (2005), Nemeat- Alla et al. (2007a) and Nemeat-Alla et al. (2009) reported that root dimensions significantly affected by application with micronutrients which gave maximum root dimensions. Concluded that maximum dry matter was obtained when sugar beet fertilized with micronutrients, the highest top, root and sugar yield by high rate of nitrogen and gave micronutrients produced maximum by Abd El- Hadi et al. (2002), Ramadan \& Nassar (2004), Nemeat-Alla (2005) and Nemeat-Alla et al. (2009). On the other hand, the high levels of nitrogen or micronutrients gave the lowest values of quality characters such as sucrose total soluble solids and purity percentages as reported by Ramadan \& Nassar (2004), Aboushady et al. (2007), Nemeat-Alla et al. (2009) and Salim et al. (2012).

The objective of this study was increasing sugar beet productivity by determine the optimum nitrogen rate and micronutrients of sugar beet at Sakha, Kafrelshiek Governorate.

\section{Materials and Methods}

Two field experiments were carried out at the Experimental Farm of Sakha Agricultural Research Station, Agricultural Research Center, Egypt, during 2012/2013 and 2013/2014 seasons. The preceding crop was maize in the two seasons. The chemical analysis of the experimental soil is presented in Table 1. A split plot design with three replicates was used, the main plots were occupted by micronutrient spraying whereas, the nitrogen fertilizer rates were allocated in the sub-plots. The studied fertilizer treatments were as follows:

\section{Spraying treatments}

1. Spraying with, water.

2. Spraying with micronutrients mixture once after 60 days from sowing.

3. Spraying with micronutrients mixture twice after 60 and 75 days from sowing. 


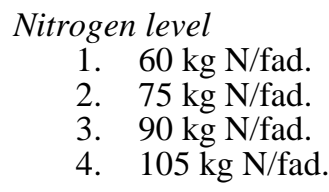

TABLE 1. Chemical analysis of the experimental soil $(0-30 \mathrm{~cm}$ in depth) $(2012 / 2013$ and 2013/2014).

\begin{tabular}{|c|c|c|c|c|c|c|c|c|c|c|}
\hline \multirow{2}{*}{ Season } & PH & EC & Organic & Fe & Zn & Mo & Mn & B & Cu \\
\cline { 5 - 10 } & $\mathbf{1 . 2 - 5}$ & Mmhas/cm & mater\% & \multicolumn{7}{|c|}{ Meq/l } \\
\hline $2010 / 2011$ & 8.2 & 3.45 & 1.82 & 0.72 & 0.44 & 0.23 & 1.88 & 0.39 & 0.53 \\
\hline $2011 / 2012$ & 8.1 & 3.31 & 1.85 & 0.75 & 0.40 & 0.24 & 1.97 & 0.38 & 0.56 \\
\hline
\end{tabular}

Solution of micronutrients mixture include iron sulphate, zinc sulphate, ammonium molybdate, manganes sulphate and boric acid (each at the rate of $1.0 \mathrm{~g} / 1$ ) in addition to copper sulphate (at the rates of $0.5 \mathrm{~g} / \mathrm{l}$ ). Each sub-plot has five ridges $60 \mathrm{~cm}$ apart and $7 \mathrm{~m}$ long. Sowing took place on $15^{\text {th }}$ Nov. and $17^{\text {th }}$ Nov. in both seasons, respectively.

Seed of multigerm cultivar "top" was sown in hill $20 \mathrm{~cm}$ apart. Plants were thinned to one plant per hill after 4 true leaves from sowing. Nitrogen was applied in the from of Urea $(46 \% \mathrm{~N})$ in two equal doses. The first one was applied after thinning and the $2^{\text {nd }}$ dose 25 days later. The other cultural practices for growing sugar beet were conducted as recommended.

At maturing (205 days from sowing), a sample of 10 plants was taken at random to determine root dimensions and dry matter accumulation. TSS\% was determine by using hand Refractometer, sucrose percentage was determine according to Le Docte (1927) and juice purity percentage was calculated according the following equation according to Silin \& Silina ( 1977).

\section{Purity $\%=$ Sucrose $\% /$ TSS $\%$.}

Sugar yield per faddan was calculated according the following equation.

Sugar yield $($ ton $/$ fad $)=$ Root yield $($ ton $/$ fad $) \times$ Sucrose $\%$.

The analysis of variance was carried out according to Gomez \& Gomez (1984). Treatment means were compared by Duncan's multiple Range test (Duncan, 1955). All statistical analysis were performed using analysis of variance technique by means of "MSTAT" computer software package.

\section{Agronomical studies}

\section{Results and Discussion}

Growth characters

Root dimensions (length and diameter) were significantly affected by spraying with micronutrients mixture in the two seasons (Table 2). Sugar beet plants, which sprayed with micronutrients mixture twice was superior in root length and diameter compared to other treatments. These results are in line with those reported by Nemeat-Alla \& El-Geddawy (2001) and Nemeat-Alla \& Mohamed (2005). 
TABLE 2. Root length and root diameter $(\mathrm{cm})$ as affected micronutrients foliar spray and nitrogen fertilizer (2012/2013 and 2013/2014 seasons).

\begin{tabular}{|l|c|c|c|c|}
\hline \multirow{2}{*}{ Factor } & \multicolumn{2}{c|}{ Root length $(\mathbf{c m})$} & \multicolumn{2}{c|}{ Root diameter $(\mathbf{c m})$} \\
\cline { 2 - 5 } & $\mathbf{2 0 1 2 / 2 0 1 3}$ & $\mathbf{2 0 1 3 / 2 0 1 4}$ & $\mathbf{2 0 1 2 / 2 0 1 3}$ & $\mathbf{2 0 1 3 / 2 0 1 4}$ \\
\hline Micronutrient & $*$ & $*$ & $*$ & $*$ \\
\hline Water & $28.43 \mathrm{c}$ & $29.62 \mathrm{c}$ & $10.89 \mathrm{c}$ & $11.29 \mathrm{c}$ \\
\hline MN-Once & $28.94 \mathrm{~b}$ & $30.14 \mathrm{~b}$ & $11.18 \mathrm{~b}$ & $12.18 \mathrm{a}$ \\
\hline MN-Twice & $29.85 \mathrm{a}$ & $31.17 \mathrm{a}$ & $12.04 \mathrm{a}$ & $12.41 \mathrm{a}$ \\
\hline N. rate $(\mathrm{kg} \mathrm{N} / \mathrm{fad})$ & $* *$ & $* *$ & $* *$ & $* *$ \\
\hline 60 & $26.15 \mathrm{~d}$ & $27.23 \mathrm{~d}$ & $9.51 \mathrm{~d}$ & $10.25 \mathrm{~d}$ \\
\hline 75 & $28.32 \mathrm{c}$ & $29.16 \mathrm{c}$ & $10.9 \mathrm{c}$ & $11.53 \mathrm{c}$ \\
\hline 90 & $29.77 \mathrm{~b}$ & $31.19 \mathrm{~b}$ & $11.8 \mathrm{~b}$ & $11.92 \mathrm{~b}$ \\
\hline 105 & $31.56 \mathrm{a}$ & $33.04 \mathrm{a}$ & $13.27 \mathrm{a}$ & $14.13 \mathrm{a}$ \\
\hline Interaction & $*$ & $*$ & $*$ & N.S \\
\hline
\end{tabular}

$*$ and N.S indicated $\mathrm{P}<0.05$ and not significant, respectively. Means within the same column for each factor designed by the same letter are not significantly different at 5\% level according to Duncan's multiple range test. $\mathrm{MN}$ (micronutrients ).

Increasing nitrogen level from 60 to $105 \mathrm{~kg} / \mathrm{N}$ fad significantly increased root dimensions (length and diameter) at harvest in both seasons. The highest values of root length and diameter was recorded at the level of $105 \mathrm{~kg} \mathrm{~N} / \mathrm{fad}$ This result is in agreement with Neameat-Alla \& El-Geddawy (2001) which concluded that $115 \mathrm{~kg} \mathrm{~N} / \mathrm{fad}$ caused significant effect on root diameter.

The interaction between micronutrients foliar spray and nitrogen rate had significant effect on root length in two seasons, while root diameter affected in the first season only (Tables 3 and 4 ). Beet plants sprayed two times with micronutrients mixture under $105 \mathrm{~kg} \mathrm{~N} /$ fad produced the highest root length and diameter. While beet plants of the control treatment and nitrogen rate $60 \mathrm{~kg}$ $\mathrm{N} /$ fad gave the lowest root length and diameter.

TABLE 3. Root length as affected by the interaction between micronutrients foliar spray fertilizer (2012/2013 and 2013/2014 seasons).

\begin{tabular}{|l|c|c|c|c|}
\hline \multirow{2}{*}{ Micronutrients } & \multicolumn{5}{|c|}{ N. rate (kg N/fad) } \\
\cline { 2 - 5 } & $\mathbf{6 0}$ & $\mathbf{7 5}$ & $\mathbf{9 0}$ & $\mathbf{1 0 5}$ \\
\hline \multicolumn{5}{|c|}{$2012 / 2013$ seasons } \\
\hline Water & $24.95 \mathrm{~h}$ & $27.84 \mathrm{ef}$ & $30.00 \mathrm{c}$ & $30.95 \mathrm{~b}$ \\
\hline MN-Once & $24.87 \mathrm{~g}$ & $28.37 \mathrm{de}$ & $30.08 \mathrm{c}$ & $30.98 \mathrm{~b}$ \\
\hline MN-Twice & $25.73 \mathrm{f}$ & $28.75 \mathrm{~d}$ & $30.73 \mathrm{c}$ & $32.75 \mathrm{a}$ \\
\hline \multicolumn{5}{|c|}{$2013 / 2014$ seasons } \\
\hline Water & $27.00 \mathrm{~h}$ & $28.71 \mathrm{f}$ & $30.35 \mathrm{de}$ & $32.42 \mathrm{~b}$ \\
\hline MN-Once & $27.62 \mathrm{~g}$ & $29.15 \mathrm{ef}$ & $31.15 \mathrm{~cd}$ & $32.63 \mathrm{~b}$ \\
\hline MN-Twice & $28.88 \mathrm{f}$ & $29.08 \mathrm{c}$ & $32.08 \mathrm{c}$ & $34.07 \mathrm{a}$ \\
\hline
\end{tabular}

Means designed by the same letter are not significantly at 5\% level, using Duncan's multiple range test. MN (micronutrients ).

Egypt. J. Agron. 36, No. 2 (2014) 
TABLE 4. Root diameter (cm) as affected by the interaction between micronutrients foliar spray and nitrogen fertilizer (2012/2013 season).

\begin{tabular}{|l|c|c|c|c|}
\hline \multirow{2}{*}{ Micronutrients } & \multicolumn{5}{|c|}{ N. rate (kg N/fad) } \\
\cline { 2 - 5 } & $\mathbf{6 0}$ & $\mathbf{7 5}$ & $\mathbf{9 0}$ & $\mathbf{1 0 5}$ \\
\hline Without spraying & $8.93 \mathrm{~g}$ & $10.71 \mathrm{ef}$ & $11.18 \mathrm{~cd}$ & $12.47 \mathrm{~b}$ \\
\hline Water & $9.28 \mathrm{~g}$ & $10.92 \mathrm{ef}$ & $11.53 \mathrm{c}$ & $13.00 \mathrm{~b}$ \\
\hline MN-Once & $10.32 \mathrm{f}$ & $11.07 \mathrm{de}$ & $12.68 \mathrm{~b}$ & $14.07 \mathrm{a}$ \\
\hline MN-Twice &
\end{tabular}

Means designed by the same letter are not significantly at $5 \%$ level, using Duncan's multiple range test.

\section{Dray matter accumulation (g/plant)}

Foliar application of micronutrients mixture had a significant effect on dry matter accumulation in both seasons (Table 5). Plants sprayed with micronutrients mixture twice substantially recorded the greatest dry matter accumulation, while the lowest one was associated with control (spraying with water). Similar results were obtained by Nemeat-Alla \& El-Geddawy (2001).

TABLE 5. Dray matter accumulation (g/plant) and root/top ratio\% as affected by micronutrients foliar spray and nitrogen fertilizer in 2012/2013 and 2013/2014 seasons.

\begin{tabular}{|l|c|c|c|c|}
\hline \multirow{2}{*}{ Factor } & \multicolumn{2}{|c|}{ Dray matter (g/plant) } & \multicolumn{2}{c|}{ root/top ratio\% } \\
\cline { 2 - 5 } & $\mathbf{2 0 1 2 / 2 0 1 3}$ & $\mathbf{2 0 1 3 / 2 0 1 4}$ & $\mathbf{2 0 1 2 / 2 0 1 3}$ & $\mathbf{2 0 1 3 / 2 0 1 4}$ \\
\hline Micronutrients & $* *$ & $* *$ & $* *$ & $* *$ \\
\hline Water & $203.77 \mathrm{c}$ & $206.05 \mathrm{c}$ & $4.72 \mathrm{c}$ & $4.41 \mathrm{~b}$ \\
\hline MN-Once & $207.01 \mathrm{~b}$ & $209.97 \mathrm{~b}$ & $4.86 \mathrm{~b}$ & $4.55 \mathrm{a}$ \\
\hline MN-Twice & $209.11 \mathrm{a}$ & $211.00 \mathrm{a}$ & $5.05 \mathrm{a}$ & $4.68 \mathrm{a}$ \\
\hline N. rate $(\mathrm{kg} \mathrm{N/fad)}$ & $* *$ & $* *$ & $* *$ & $* *$ \\
\hline 60 & $202.87 \mathrm{c}$ & $203.43 \mathrm{~d}$ & $5.06 \mathrm{a}$ & $4.68 \mathrm{a}$ \\
\hline 75 & $203.84 \mathrm{bc}$ & $206.77 \mathrm{c}$ & $4.88 \mathrm{~b}$ & $4.55 \mathrm{~b}$ \\
\hline 90 & $205.29 \mathrm{~b}$ & $208.44 \mathrm{~b}$ & $4.87 \mathrm{~b}$ & $4.53 \mathrm{~b}$ \\
\hline 105 & $214.22 \mathrm{a}$ & 217.40 & $7.70 \mathrm{c}$ & $4.43 \mathrm{c}$ \\
\hline Interaction & $* *$ & $*$ & N.S & N.S \\
\hline
\end{tabular}

$*$ and N.S indicated $\mathrm{P}<0.05$ and not significant, respectively. Means within the same column for each factor designed by the same letter are not significantly different at 5\% level according to Duncan's multiple range test. $\mathrm{MN}$ (micronutrients ).

Nitrogen rate had a significant effect on dry matter accumulation (g / plant) in the both seasons (Table 5). Application of $105 \mathrm{~kg} \mathrm{~N} /$ fad produced the highest dry matter accumulation in the two seasons, while application of $60 \mathrm{~kg} \mathrm{~N} /$ fad produced the lowest dry matter accumulation per plant. Similar results were obtained by El-Zayat (2000), Badr (2004), Nemeata-Alla (2005), Nemeat-Alla et al. (2007), El-Fadaly et al. (2011) and Essam et al. (2012).

The interaction between micronutrients foliar spray and nitrogen rates had a significant effect on dry matter accumulation/plant in the two seasons (Table 6). Spraying micronutrients twice nitrogen rates in combination with $105 \mathrm{~kg} \mathrm{~N} / \mathrm{fad}$ resulted in the highest dry matter accumulation at harvest in both seasons.

Egypt. J. Agron. 36, No. 2 (2014) 
TABLE 6. Dry matter as affected by the interaction between micronutrients foliar spray and nitrogen fertilizer (2012/2013 and 2013/2014 seasons).

\begin{tabular}{|l|c|c|c|c|}
\hline \multirow{2}{*}{ Micronutrints } & \multicolumn{5}{|c|}{ N. rate (kg N/fad) } \\
\cline { 2 - 5 } & $\mathbf{6 0}$ & $\mathbf{7 5}$ & $\mathbf{9 0}$ & $\mathbf{1 0 5}$ \\
\hline Water & $201.56 \mathrm{~g}$ & $202.52 \mathrm{fg}$ & $203.90 \mathrm{ef}$ & $207.12 \mathrm{c}$ \\
\hline MN-Once & $202.99 \mathrm{fg}$ & $203.94 \mathrm{ef}$ & $205.86 \mathrm{~cd}$ & $215.35 \mathrm{~b}$ \\
\hline MN-Twice & $204.07 \mathrm{ef}$ & $205.16 \mathrm{de}$ & $207.00 \mathrm{c}$ & $220.20 \mathrm{a}$ \\
\hline \multicolumn{5}{|c|}{$2013 / 2014$ seasons } \\
\hline Water & $201.84 \mathrm{i}$ & $205.83 \mathrm{fg}$ & $207.69 \mathrm{de}$ & $208.85 \mathrm{~cd}$ \\
\hline MN_Once & $203.69 \mathrm{~h}$ & $208.60 \mathrm{ef}$ & $208.53 \mathrm{~cd}$ & $220.88 \mathrm{~b}$ \\
\hline MN-Twice & $204.76 \mathrm{gh}$ & $207.69 \mathrm{de}$ & $209.09 \mathrm{c}$ & $222.46 \mathrm{a}$ \\
\hline
\end{tabular}

Means designed by the same letter are not significantly at 5\% level, using Duncan's multiple range test. MN (micronutrients ).

\section{Root/top ratio}

Data given in Table 5 revealed the effect of foliar application of micronutrients mixture and nitrogen rate on root / top ratio (calculated on base of dry weight). Spraying micronutrients resulted in highly significant differences in root/top ratio in plants sprayed twice compared with those sprayed once.

Nitrogen rate exerted highly significant effect on root/top ratio in both seasons. Adding $105 \mathrm{~kg} \mathrm{~N} /$ fad produced the highest root/top ratio in the two seasons, while adding $60 \mathrm{~kg} \mathrm{~N} / \mathrm{fad}$ produced the lowest value in the two seasons. In the connections Hassanin \& El-Elayan (2000), Nemeat-Alla et al. (2002) and Nemeat-Alla (2005) showed that root/top ratio was increased with increasing $\mathrm{N}$ - fertilizer when soil $\mathrm{N}$ is limited.

The interaction between spraying micronutrients and nitrogen rate had significant effect on root/top ratio in both seasons (Table 6).

\section{Top, root and sugar yield/fad}

\section{Top yield (ton/fad).}

Data presented in Table 7 indicated that spraying of micronutrients mixture increased top yield in both seasons. Application of micronutrients mixture twice gave the highest top yield/fad. The obtained results are in agreement with those found by Nemeat-Alla \& El-Geddawy (2001).

Nitrogen level of $105 \mathrm{~kg} \mathrm{~N} /$ fad significantly increased top yield to maximum values (11.58 and $12.04 \mathrm{ton} / \mathrm{fad})$ in the first and second season, respectively. These observations are in agreement with those reports by Zalat \& Ibrahim (2002), Mostafa et.al. (2005) and Moustafa (2006).

The interaction between spraying micronutrients mixture and nitrogen level had a significant effect on top yield in both seasons (Table 7). Table 8 shows that the maximum weight of top yield was produced with combination of applying $105 \mathrm{~kg} \mathrm{~N} / \mathrm{fed}$ and foliar twice micronutrients.

Egypt. J. Agron. 36, No. 2 (2014) 
TABLE 7. Top, root and sugar yield (ton/fad) as affected by spraying micronutrients and nitrogen fertilizer in 2012/2013 and 2013/2014 seasons.

\begin{tabular}{|c|c|c|c|c|c|c|}
\hline \multirow{2}{*}{ Factor } & \multicolumn{2}{|c|}{$\begin{array}{c}\text { Top yield } \\
\text { (ton/fad) }\end{array}$} & \multicolumn{2}{c|}{$\begin{array}{c}\text { Root yield } \\
\text { (ton/fad) }\end{array}$} & \multicolumn{2}{c|}{$\begin{array}{c}\text { Sugar yield } \\
\text { (ton/fad) }\end{array}$} \\
\cline { 2 - 7 } & $\mathbf{2 0 1 2 / 1 3}$ & $\mathbf{2 0 1 3 / 1 4}$ & $\mathbf{2 0 1 2 / 1 3}$ & $\mathbf{2 0 1 3 / 1 4}$ & $\mathbf{2 0 1 2 / 1 3}$ & $\mathbf{2 0 1 3 / 1 4}$ \\
\hline Micronutrients & $*$ & $*$ & $*$ & $*$ & $*$ & $*$ \\
\hline Water & $8.53 \mathrm{c}$ & $8.57 \mathrm{c}$ & $26.27 \mathrm{c}$ & $27.21 \mathrm{c}$ & $3.75 \mathrm{c}$ & $4.02 \mathrm{c}$ \\
\hline MN-Once & $9.46 \mathrm{~b}$ & $9.92 \mathrm{~b}$ & $27.08 \mathrm{~b}$ & $27.99 \mathrm{~b}$ & $3.82 \mathrm{~b}$ & $4.10 \mathrm{~b}$ \\
\hline MN-Twice & $9.54 \mathrm{a}$ & $10.62 \mathrm{a}$ & $27.87 \mathrm{a}$ & $28.78 \mathrm{a}$ & $3.87 \mathrm{a}$ & $4.19 \mathrm{a}$ \\
\hline N. rate (kg N/fad) & $*$ & $* *$ & $*$ & $* *$ & $*$ & $*$ \\
\hline 60 & $7.32 \mathrm{~d}$ & $7.79 \mathrm{~d}$ & $24.43 \mathrm{~d}$ & $26.03 \mathrm{~d}$ & $3.61 \mathrm{c}$ & $3.93 \mathrm{c}$ \\
\hline 75 & $8.85 \mathrm{c}$ & $9.55 \mathrm{c}$ & $27.08 \mathrm{c}$ & $29.81 \mathrm{c}$ & $3.82 \mathrm{~b}$ & $4.42 \mathrm{~b}$ \\
\hline 90 & $9.61 \mathrm{~b}$ & $10.11 \mathrm{~b}$ & $27.98 \mathrm{~b}$ & $32.06 \mathrm{~b}$ & $3.24 \mathrm{~b}$ & $4.66 \mathrm{a}$ \\
\hline 105 & $11.58 \mathrm{a}$ & $12.04 \mathrm{a}$ & $28.81 \mathrm{a}$ & $34.08 \mathrm{a}$ & $3.96 \mathrm{a}$ & $4.69 \mathrm{a}$ \\
\hline Interaction & $*$ & $*$ & $*$ & $*$ & N.S & N.S \\
\hline
\end{tabular}

* and N.S indicated $\mathrm{P}<0.05$ and not significant, respectively. Means within the same column for each factor designed by the same letter are not significantly different at $5 \%$ level according to Duncan's multiple range test. $\mathrm{MN}$ (micronutrients ).

TABLE 8. Top yield as affected by the interaction between spraying micronutrients and nitrogen fertilizer (2012/2013 and 2013/2014seasons).

\begin{tabular}{|l|c|c|c|c|}
\hline \multirow{2}{*}{ Micronutrients } & \multicolumn{4}{|c|}{ N. rate (kg N/fad) } \\
\cline { 2 - 5 } & $\mathbf{6 0}$ & $\mathbf{7 5}$ & $\mathbf{9 0}$ & $\mathbf{1 0 5}$ \\
\hline \multicolumn{5}{|c|}{$2012 / 2013$ seasons } \\
\hline Water & $6.30 \mathrm{~h}$ & $8.07 \mathrm{~d}$ & $9.07 \mathrm{ed}$ & $10.67 \mathrm{c}$ \\
\hline MN-Once & $7.50 \mathrm{~g}$ & $8.98 \mathrm{ed}$ & $9.62 \mathrm{~d}$ & $11.73 \mathrm{~b}$ \\
\hline MN-Twice & $8.16 \mathrm{f}$ & $9.50 \mathrm{~d}$ & $10.15 \mathrm{~cd}$ & $12.34 \mathrm{a}$ \\
\hline \multicolumn{5}{|c|}{$2013 / 2014$ seasons } \\
\hline Water & $6.83 \mathrm{~h}$ & $8.68 \mathrm{de}$ & $9.62 \mathrm{~d}$ & $11.17 \mathrm{c}$ \\
\hline MN-Once & $7.86 \mathrm{~g}$ & $9.64 \mathrm{~d}$ & $10.08 \mathrm{~d}$ & $12.10 \mathrm{~b}$ \\
\hline MN-Twice & $8.67 \mathrm{f}$ & $10.33 \mathrm{~cd}$ & $10.62 \mathrm{c}$ & $12.84 \mathrm{a}$ \\
\hline
\end{tabular}

Means designed by the same letter are not significantly at $5 \%$ level, using Duncan's multiple range test. MN (micronutrients ).

Root yield (ton/fad)

It is clear from Table 7 that spraying micronutrients mixture twice significantly increased root yield/fad to maximum values ( 27.87 and 28.78 ton/fad) in the first and second season, respectively. Similar results were obtained by Nemeat-Alla \& El-Geddawy (2001).

Nitrogen rate exerted significant effect on root yield per faddan in the two seasons. Application at $105 \mathrm{~kg} \mathrm{~N} /$ fad produced the highest root yield in the two seasons. The lowest root yield per faddan was recorded at minimum nitrogen rate. Similar results were obtained by Nemeat-Alla \& EL-Geddawy (2001) who found that increasing nitrogen level significantly increased root yield. 
The effect of interaction between spraying micronutrients mixture and nitrogen rate was significant on root yield per faddan in both seasons, (Table 9). The highest root yields was obtained with spraying micronutrients mixture and soil application of $105 \mathrm{~N} /$ fad. While the lowest root yield were obtained with spraying micronutrients mixture and application of $60 \mathrm{~kg} \mathrm{~N} / \mathrm{fad}$

TABLE 9. Root yield as affected by the interaction between spraying micronutrients and nitrogen fertilizer (2012/2013and 2013/2014 seasons).

\begin{tabular}{|l|c|c|c|c|}
\hline \multirow{2}{*}{ Micronutrients } & \multicolumn{4}{|c|}{ N. rate (kg N/fad) } \\
\cline { 2 - 5 } & $\mathbf{6 0}$ & $\mathbf{7 5}$ & $\mathbf{9 0}$ & $\mathbf{1 0 5}$ \\
\hline \multicolumn{5}{|c|}{$2012 / 2013$ seasons } \\
\hline Water & $23.72 \mathrm{f}$ & $26.27 \mathrm{~cd}$ & $27.12 \mathrm{c}$ & $27.97 \mathrm{~b}$ \\
\hline MN-Once & $24.47 \mathrm{e}$ & $27.04 \mathrm{c}$ & $28.08 \mathrm{~b}$ & $28.75 \mathrm{~b}$ \\
\hline MN-Twice & $25.10 \mathrm{~d}$ & $27.92 \mathrm{c}$ & $28.75 \mathrm{~b}$ & $29.70 \mathrm{a}$ \\
\hline \multicolumn{5}{|c|}{$2013 / 2014$ seasons } \\
\hline Water & $23.40 \mathrm{~h}$ & $25.10 \mathrm{e}$ & $29.28 \mathrm{~cd}$ & $31.06 \mathrm{~b}$ \\
\hline MN-Once & $24.09 \mathrm{~g}$ & $26.70 \mathrm{de}$ & $29.70 \mathrm{~cd}$ & $23.02 \mathrm{~b}$ \\
\hline MN-Twice & $24.75 \mathrm{f}$ & $26.84 \mathrm{e}$ & $30.44 \mathrm{c}$ & $33.09 \mathrm{a}$ \\
\hline
\end{tabular}

Means designed by the same letter are not significantly at $5 \%$ level, using Duncan's multiple range test. MN (micronutrients ).

\section{Sugar yield (ton/fad)}

Data presented in Table 7 indicated that sugar yield was significantly influenced by foliar application of micronutrients in the two seasons. Beet plants which were sprayed twice by micronutrients mixture exceeded those sprayed once in sugar yield in the two seasons. In both seasons, sugar yield per faddan was significantly affected by nitrogen rate. The highest sugar yield resulted from $105 \mathrm{~kg} \mathrm{~N} /$ fad in both seasons (Table 7). It worth mentioning that depressive effect of nitrogen on sugar \% and juice purity \% was compensated by higher root yield and finally increased sugar yield/fad. Similar results were obtained by Zalat \& Ibrahim (2002), Ismail \& AboEl-Ghait (2005), Moustafa (2006), Aboushady et al. (2007), El-Fadaly et al. (2011) and Salim et al. (2012). Interaction between foliar spray of micronutrient and soil applied nitrogen had no significant effect on this trait in both seasons.

\section{Quality parameters}

Total soluble solids percentage (TSS\%)

From Table 10 it is clear that TSS\% was significantly affected by foliar application of micronutrients in both seasons. TSS\% was gradually decreased by increasing application of micronutrients mixture.

Increasing nitrogen level from 60 to $105 \mathrm{~kg} \mathrm{~N} /$ fad decreased TSS\% at harvest in both seasons. TSS\% was decreased from 21.58 and 21.46 to 19.92 and $20.61 \%$ as N-level increased from 60 to $105 \mathrm{~kg} \mathrm{~N} /$ fad in the two seasons, respectively. Hassanin \& El-Elayan (2000), Nemeat-Alla \& El-Geddawy (2001) and Badr (2004) came to similar results and same conclusion.

The interaction effect between spraying micronutrients mixture and nitrogen rate was not significant on TSS\% in the two seasons.

Egypt. J. Agron. 36, No. 2 (2014) 
TABLE 10. Total soluble solids (TSS\%), sucrose percentage and juice purity as affected by spraying micronutrients and nitrogen fertilizer in 2012/2013 and 2013/2014 seasons.

\begin{tabular}{|l|c|c|c|c|c|c|}
\hline \multirow{2}{*}{ Factor } & \multicolumn{2}{|c|}{ TSS\% } & \multicolumn{2}{c|}{$\begin{array}{c}\text { Sucrose } \\
\text { percentage\% }\end{array}$} & \multicolumn{2}{c|}{ Juice purity \% } \\
\cline { 2 - 7 } & $\mathbf{2 0 1 2 / 1 3}$ & $\mathbf{2 0 1 3 / 1 4}$ & $\mathbf{2 0 1 2 / 1 3}$ & $\mathbf{2 0 1 3 / 1 4}$ & $\mathbf{2 0 1 2 / 1 3}$ & $\mathbf{2 0 1 3 / 1 4}$ \\
\hline Micronutrients & $*$ & $* *$ & $*$ & $*$ & $*$ & $*$ \\
\hline Water & $21.07 \mathrm{a}$ & $21.43 \mathrm{a}$ & $14.27 \mathrm{a}$ & $14.77 \mathrm{a}$ & $80.27 \mathrm{a}$ & $73.24 \mathrm{a}$ \\
\hline MN-Once & $20.67 \mathrm{~b}$ & $21.10 \mathrm{~b}$ & $14.10 \mathrm{~b}$ & $14.65 \mathrm{~b}$ & $79.29 \mathrm{~b}$ & $71.43 \mathrm{~b}$ \\
\hline MN-Twice & $20.53 \mathrm{c}$ & $20.93 \mathrm{c}$ & $13.90 \mathrm{c}$ & $14.56 \mathrm{c}$ & $79.39 \mathrm{c}$ & $71.59 \mathrm{~b}$ \\
\hline $\begin{array}{l}\text { N. rate }(\mathrm{kg} \\
\text { N/fad) }\end{array}$ & $*$ & $*$ & $*$ & $*$ & $* *$ & $* *$ \\
\hline 60 & $21.58 \mathrm{a}$ & $21.46 \mathrm{a}$ & $14.78 \mathrm{a}$ & $15.11 \mathrm{a}$ & $83.63 \mathrm{a}$ & $72.54 \mathrm{a}$ \\
\hline 75 & $20.69 \mathrm{~b}$ & $21.32 \mathrm{a}$ & $14.12 \mathrm{~b}$ & $14.83 \mathrm{~b}$ & $78.97 \mathrm{~b}$ & $71.54 \mathrm{~b}$ \\
\hline 90 & $20.54 \mathrm{c}$ & $21.21 \mathrm{~b}$ & $13.73 \mathrm{c}$ & $14.52 \mathrm{c}$ & $78.49 \mathrm{c}$ & $70.39 \mathrm{c}$ \\
\hline 105 & $19.92 \mathrm{~d}$ & $20.61 \mathrm{c}$ & $13.75 \mathrm{c}$ & $13.77 \mathrm{~d}$ & $76.54 \mathrm{c}$ & $68.71 \mathrm{~d}$ \\
\hline Interaction & N.S & N.S & N.S & N.S & N.S & N.S \\
\hline
\end{tabular}

* and N.S indicated $\mathrm{P}<0.05$ and not significant, respectively. Means within the same column for each factor designed by the same letter are not significantly different at 5\% level according to Duncan's multiple range test. $\mathrm{MN}$ (micronutrients ).

\section{Sucrose percentage}

Data in Table 10 show that sucrose percentage was significantly affected by foliar application of micronutrients in the two seasons. The lowest sucrose percentage was obtained from application of beet plants sprayed with micronutrients mixture twice compared with those sprayed once.

Increasing nitrogen fertilization significantly decreased sucrose concentration in beet root in both seasons. The lowest percentage of sucrose was recorded by $105 \mathrm{~kg}$ $\mathrm{N} / \mathrm{fad}$ in the two seasons. Similar results were obtained by Abo EL-Wafa (2002), Moustafa (2006), Ouda (2007), El-Fedaly et al. (2011) and Essam et al. (2012). The interacrion effect between spraying micronutrients mixture and nitrogen rate was not significant on sucrose percentage in the two seasons .

\section{Juice purity percentage}

The results in the Table 10 showed that repeating foliar spray with micronutrients mixture decreased juice purity percentage in sugar beet root in both seasons. Similar results were obtained by Nemeat-Alla \& El-Geddawy (2001).

Juice purity was decreased significantly by increasing nitrogen rate up to $105 \mathrm{~kg} \mathrm{~N} / \mathrm{fad}$. This results is similar to that of El-Geddawy et.al. (2007), Abo El-Wafa (2002), Ismail (2002), Nemeat-Alla (2005), Nemeata-Alla et al. (2009) and Essam et al. (2012).

None of interaction had significant effect on juice purity percentage in both seasons. 
Generally, it can be concluded that the high rate of nitrogen $(105 \mathrm{~kg} / \mathrm{fad})$ in combination with spraying beet plants twicely with mixture of micronutrients can achieve maximum yield and quality.

\section{Refrences}

Abd El-Gawad, A.M., Allam, S.A.H., Saif, L.M.A. and Dsamen, A.M.H. (2004) Effect of some micronutrients on yield and quality of sugar beet (Beta vulgaris L. ). Juice quality and chemical composition. Egypt. J. Agric. Res. 82(4), 1681-1701.

Abd El-Hadi, A.H., Aly, M.A., Attat, A.A., Zidan, M.A. and Zahran, F. (2002) Response of sugar beet to various forms and rates of nitrogen fertilizer. Egyptian $J$. Soil Sci. 4, 643-658.

Abo El-Wafa, A.M. (2002) Effect of plant spacing, nitrogen rate and frequency on yield and quality of Kawemira sugar beet variety under Upper Egypt. J. Agric. Sci. Mansoura Univ. 27 (2), 707-716.

Aboushady, Kh., Nemeat-Alla, E.A.E. and Yousef, Nariman O.A. (2007) Effect of level and time of nitrogen application and harvesting date on yield and quality of sugar beet (Beta vulgaris L.). Minufia. J. Agric. 32 (5),1403-1417.

Allam, S.M. (2008) Quality, technological and productivity apects of sugar beet as influence by nitrogen, potassium and boron fertilizer. Egypt J. Appl. Sci. 23(1), 141-151.

Azab, M.A., El-Hawary, M.A., Farag, H.A. and Ali, M.S. (2000) Effect of soil and foliar nitrogen on suagr beet in newly reclaimed soil. J. Agric. Sci. Mansoura Univ. 25 (11), 6681-6690.

Badr, A.I. (2004) Response of sugar beet plant to mineral and biological fertilization in North Delta. Ph.D. Thesis, Fac. Agric., AL-Azhar Univ., Egypt.

Duncan, B.D. (1955) Multiple range and multiple F. test. Biometric, 11, 1-42.

El-Fadaly, H.A., El-Geddawy, I.H. El-Haawary, F.I. and Abo EL-Rahman, I.A. (2011) Effect of biofertilization on sugar beet yield and its components, Fayoum J. Agric. Res. Devel. 25.

El- Geddawy, I.H., El-Hosary, A.A. Saad, A.M.M. and Ibrahim, B.S. (2007) Effect of boron and molybdenum on growth and yield of some sugar beet varities. Egypt. J. Agric. Res. 85(4), 1355-1366.

El-Zayat, M.M.T. (2000) Effect of irrigation regime and fertilization on sugar beet. Ph.D. Thesis, Fac. Agric., Tanta Univ., Egypt.

Essam. A.S., El-Geddawy, D. I., Badawi, M.A. and Dawood, R.A. (2012) Effect of mineral and biofertilization on yield and quality components and quality traits of suagr beet plants. Fayoum J. Agric. Res. Devel. 26 (1).

Gomez, K.A. and Gomez, A.A. (1984) "Statistical Produces for Agricultural Research", $2^{\text {nd }}$ ed., Dohn Willey and Sons, New York.

Egypt. J. Agron. 36, No. 2 (2014) 
Hassanin, M.A. and El-Elayan, Sahair (2000) Effect of phosphorus and nitrogen rates and time of nitrogen application on yield and juice quality of sugar beet. J. Agric. Sci. Mansoura Univ. 25 (12), 7389-7398.

Ismail, A.M.A. (2002) Evaluation of some sugar beet varieties ayium. Egypt. J. Appl. Sci. $17(2), 2002$.

Ismail, A.M.A. and Abo El-Ghait, R.A. (2005) Effect of nitrogen sources and levels on yield and quality of sugar beet. Egypt. J. Agric. Res. 83 (1), 229-239.

LeDoct, A. (1927) Commercial determination of suagr in beet root using the saches Le Doct Process. Int. Sug. J. 488-492.

Moustafa, Shafika N. (2006) Response of some sugar beet varieties to methanol and method of nitrogen fertilizer applications. Annals of Agric. Sci., Moshtohor, 44 (1), 89-100.

Moustafa, Shafika N., El-Sayed, Safaa S.M., Gomaa, A.M.E. and Moustafa, Zeinab R. (2005) Response of sugar beet to nitrogen levels. Egypt. J. Appl. Sci. 20 (9).

Nemeat-Alla, E.A.E. (2005) Yield and quality of sugar beet as affected by different nitrogen and sulphur rates under clayey soils. J. Agric. Sci. Mansoura Univ. 30 (12), 7255-7264.

Nemeat-Alla, E.A.E. and El-Geddawy, I. H.A. (2001) response of sugar beet to foliar spraying time with micronutrients under different levels of nitrogen and phosphorus fertilization. J. Agric. Res. Tanta Univ. 27 (4), 670-681.

Nemeat-Alla, E.A.E. and Mohamed, Samia G.A. (2005) Agronomical and statistical studies on the response of sugar beet to foliar application with micronutrients under different micronutrients formula. J. Agric. Mansoura Univ. 30 (12), 7265-7284.

Nemeat-Alla, E.A.E., Mohamed, A.A.E. and Zalat, S.S. (2002) Effect of soil and foliar application of nitrogen fertilization on sugar beet. J. Agric. Sci. Mansoura Univ. 27 (3), 13431351.

Nemeat-Alla, E.A.E., Aboushady, K.A. and Youssef, N.O. (2007a) Sugar beet yield and quality as affected by sowing patterens and nitrogen levels. J. Agric. Sci. Mansoura Univ. 32 (10), 8069-8078.

Nemeat-Alla, E.A.E., Zalat, S.S. and Bader, A.I. (2009) Sugar beet yield and quality as affected by nitrogen levels and foliar application with micronutrients. J. Agric. Res. Kaferelsheikh Univ. 35(4), 995-1012.

Ouda, Sohair M.M. (2000) Effect of nitrogen fertilization with micronutrient on yield and quality of sugar beet in newly reclaimed land. Zagazig J. Agric. Res. 27 (1), 1-12.

Ouda, Sohair M.M. (2007) Effect chemical and bio fertilizer of nitrogen and boron on yield and quality of sugar beet. Zagazig J. Agric. Res. 34(1), 1-11.

Ouda, Sohier M.M. (2006) Effect of chemical and bio fertilizer of phosphorus and boron on yield quality of sugar beet. Zagazig J. Agric. Res. 34 (1), 20-28.

Ramadan, B.S.H. and Nassar, A.M. (2004) Effect of nitrogen fertilization on yield and quality of some beet varieties. Egyptian J. Agric. Res. 82 (3),1253-1268.

Salim, Fawkia M.A., Belal, A.H., Atta, M.S., Hefny, R.M. and EL-Geddawy, I.H.M. (2012) Effect of planting patterns, nitrogen levels and boron application on yield, yield components and quality of sugar beet (Beta vulgaris L.). Agric. Res. J. Suez Canal Univ. 12(2), 7-15. 
Silin, P.M. and Silina, N.P. (1977) "Chemistry Control in Sugar Technology". Food Tech. Pub USSRP. 167.

Zalat, S.S. and Ibrahim, M.F.M. (2002) The effect of levels and time of $\mathrm{N}$ application on yield and quality of transplanted sugar beet. J. Agric. Res. Alex. Univ. 7 (2), 339-348.

\section{استجابة بنجر السكر للرش بالعناصر الصغرى تحت معدلات السماد \\ النيتروجيني}

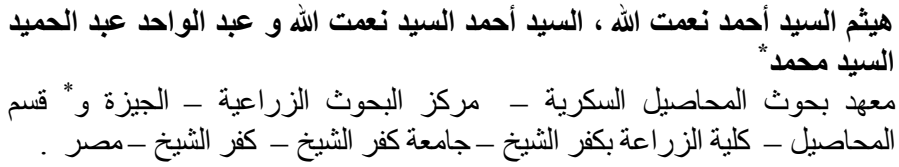

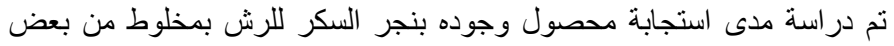

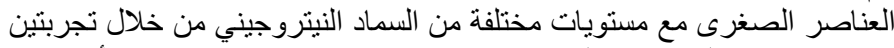

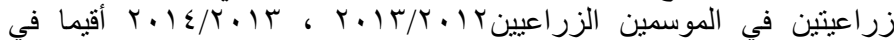

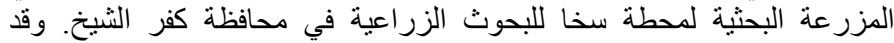

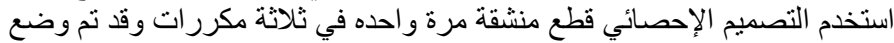

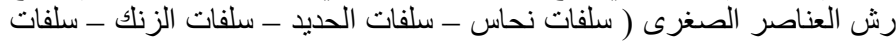

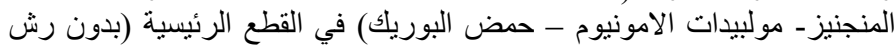

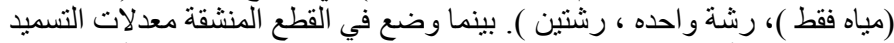

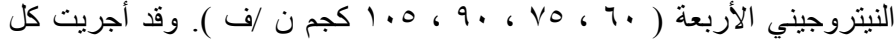

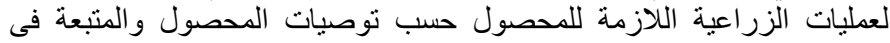

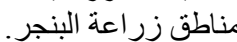

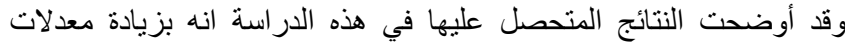

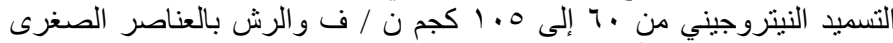

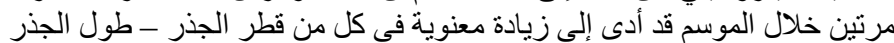

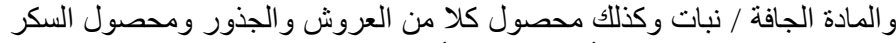

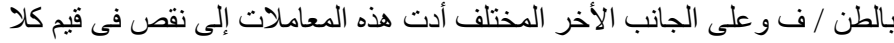

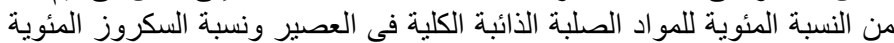

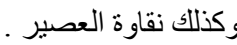

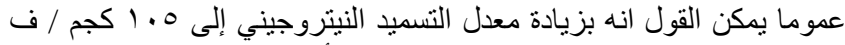

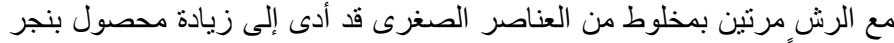
السكر كماً ونو عا تحت ظروف بر البحث في محافظة كفر الثيخ. 